\title{
Learning Activities in Physics Using Students Worksheet Based on Predict-Observe-Explain (POE)
}

\author{
Dewi Fairuz Zulaikha ${ }^{1}$, Pujianto ${ }^{2}$, Yusman Wiyatmo ${ }^{3}$ \\ Yogyakarta State University, Indonesia ${ }^{1,2,3}$ \\ dewifairuz.2020@student.uny.ac.id ${ }^{1}$, pujianto@uny.ac.id ${ }^{2}$,yusman_wiyatmo@uny.ac.id ${ }^{3}$
}

Received: December $7^{\text {th }}, 2020$. Revised: February $11^{\text {th }}, 2021$. Accepted: February $23^{\text {rd }}, 2021$

\section{Keywords :}

Active Physics;

Learning Activities;

Students Worksheet;

Predict-Observe-Explain

\begin{abstract}
This research aims to describe students learning activities through the implementation of students worksheets based on POE. This study was descriptive qualitative research. The research was conducted in one of the Islamic Senior High School in Bantul, Yogyakarta on Circular Motion material. The research subject was determined through random sampling. The number of subjects in this research consisted of 26 students in the first year. Data were collected using an observation sheet in 3 meetings observed by two persons and the interview. The results of the analysis obtained are expressed in terms of percentages and then interpreted in the form of scientific narratives. Data analysis results show that the students' worksheet based on POE can be used to enhance students' learning activities, especially in visual activities, oral activities, writing activities, motor activities, and mental activities with the most dominant activities is writing activities, and the weakest one is oral activities. Students feel that using students' worksheets based on predictobserve-explain makes them involved directly in the demonstration or the practicum, can create their curiosity, make they even more seriously in the study, increase the interest in studying physics and help each other with their friends. But, the students' confidence and speaking ability must be the concern, so students are not reluctant to share their idea in front of the class.
\end{abstract}

\section{INTRODUCTION}

Education is a service to prepare the future generation. It should be designed as student-centered learning that emphasizes active engagement [1] so that students' information is more maximal [2]. The solution that can be used to enhance students' engagement is by applying active learning in the classroom. Active learning is a method that involves the students directly instead of passively, as in the case of traditional learning [3]. Active learning has become an important pedagogical focus [4]. The decision about whether to use active learning or not are most commonly made by the teacher [5] by choosing the learning strategy or model which suitable applied in the classroom. 
One of the subjects in high school that should be learned actively is physics. Physics is considered the most problematic subject in the science scope [6]. Physics is concerned with finding out about nature systematically so that it is a process of discovery [7]. Learning physics must appropriate with the characteristic of this subject [8] through direct measurement, observation, and experiment [9]. It is physical knowledge because forming knowledge, it requires direct contact with the thing that students want to know [8]. Students need to be involved in various experiences so that they can construct and obtain a variety of scientific knowledge, skills, and attitudes [10].

In fact, according to the preliminary studies in the school, the learning process is still one direction, and the teacher is more dominant. Students were not required to practice the information conveyed by the teacher. This caused low learning activities. Students just silent, and some of them looked sleepy and even slept in the class. Students also didn't dare to express their opinion. When the teacher asked the question, students didn't want to answer.

To be able to build knowledge and skills in learning activities, it is important to develop activities in the form of an individual physically, mentally, and emotionally [11]. One of the learning strategies that can be related to students' activities is Predict-Observe-Explain [12] [13] [14]. Students' worksheet based on POE can develop their initial abilities [15] and encourage learning activities [13] [16] such as discussion activities, mental activities [17], communication activities, observational activities [15], and writing activities [4]. By applying the POE learning strategy, students are allowed to develop their knowledge and the opportunity to think, search find and explain examples of the concept applications that have been studied independently, including discussions with other peers [13].

In learning with the POE strategy, students are given the freedom to predict, observe, analyze, and draw their own conclusions [14]. The first stage in the POE learning strategy is predicting. The students predict the given problem and state the reason. Hypotheses are made based on their initial knowledge. The next stage is observing the demonstration or practicum, which provides the facts of the predicted hypothesis and the students' opinions. The last stage is explaining. In this stage, students synchronize all the differences between observations and predictions that have been made [18].

\section{METHOD}

This study was descriptive qualitative research, which aims to describe students' learning activities by implementing students worksheets based on predict-observe-explain. The research used contents analysis approach. The research was conducted in one of the Islamic Senior High School in Bantul, Yogyakarta on Circular Motion material. The research subject was determined through random sampling. The number of subjects in this research consisted of 26 students in the first year.

Data were collected using an observation sheet in 3 meetings observed by two persons and the interview. The results of the analysis obtained are expressed in terms of percentages and then interpreted in the form of scientific narratives [2]. It was a deductive approach to data analysis, meaning that a preconceived idea is looked for evidence [19]. The observation sheet is based on assessing aspects of students' learning activity detailed by the indicator showed in Table 1.

The observation sheet aims to obtain a score for learning activities for each student. The score is 1 or 0 . The percentage of achievement of students' learning activity is obtained from the total score of each indicator on the observation sheet expressed by [20]:

$$
P=\frac{\text { score obtained }}{\text { maximum score }} \times 100 \%
$$


Table 1. Students Learning Activities Indicator

\begin{tabular}{ll}
\hline \multicolumn{1}{c}{ Aspect } & \multicolumn{1}{c}{ Indicator } \\
\hline \multirow{3}{*}{ Visual activities } & 1. Pay attention to teacher or peers' explanation \\
& 2. Searching and reading various literature \\
& 3. Observe the practicum or the video well \\
\hline \multirow{3}{*}{ Oral activities } & 1. Answer question from teacher and peers \\
& 2. Ask the teacher about material that has not been \\
& 3. Anderstood \\
\hline \multirow{2}{*}{ Writing activities } & 4. Discuss in a group \\
\hline \multirow{3}{*}{ Motor activities } & 2. Answer the question in the students' worksheet \\
& 1. Do practicum according to their groups \\
& 2. Prepare experimental tools \\
\hline \multirow{2}{*}{ Mental activities } & 4. Carry out measurements \\
& 1. Respont experimental data \\
\hline
\end{tabular}

The categories of students' learning activities are determined by the following expressed by Table 2 [21]:

Table 2. The Interval and Category of Students' Learning Activities

\begin{tabular}{cc}
\hline Ranges & Category \\
\hline $81 \%-100 \%$ & Very good \\
$61 \%-80 \%$ & Good \\
$41 \%-60 \%$ & Enough \\
$21 \%-40 \%$ & Low \\
$\leq 20 \%$ & Very Low \\
\hline
\end{tabular}

\section{RESULTS AND DISCUSSIONS}

The percentage of students' learning activities in each meeting and the kind of learning activities can be explained in Table 3.

Table 3. Students' Learning Activities in Each Kind of Activities

\begin{tabular}{cccccc}
\hline Learning & \multicolumn{5}{c}{ Percentage (\%) } \\
\cline { 2 - 5 } Activities & Meeting I & Meeting II & Meeting III & Mean & \\
\hline Visual activities & 80.77 & 84.62 & 76.92 & 80.77 & Good \\
Oral activities & 61.54 & 58.97 & 58.97 & 59.83 & Enough \\
Writing Activities & 100.00 & 100.00 & 100.00 & 100.00 & Very good \\
Motor Activities & 92.31 & 100.00 & 100.00 & 97.44 & Very good \\
Mental Activities & 76.92 & 88.46 & 88.46 & 84.62 & Very good \\
\hline
\end{tabular}

The graphic of the average of students' learning activities in each activity can be seen in Figure 1 as follows. 


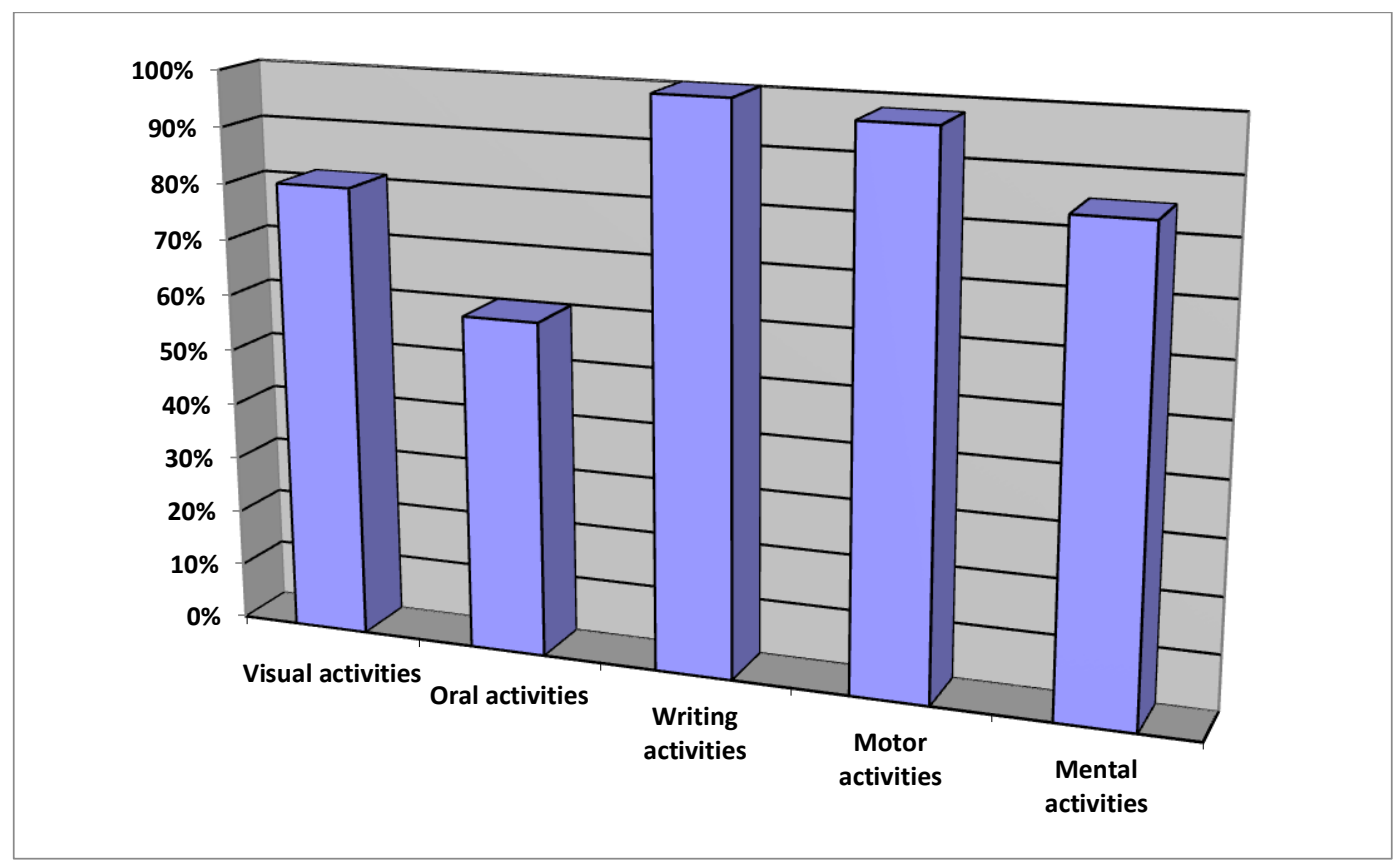

Fig 1. Students' learning activities achievement

While the achievement of students' learning activities in each interval of the percentage in every meeting is described in Table 4.

Table 4. Students' Learning Activities in Each Interval of Percentage

\begin{tabular}{cccc}
\hline Achievement of Learning & \multicolumn{3}{c}{ The Number of Students } \\
\cline { 2 - 4 } Activities & Meeting I & Meeting II & Meeting III \\
\hline $81 \%-100 \%$ & 15 & 15 & 15 \\
$61 \%-80 \%$ & 8 & 8 & 7 \\
$41 \%-60 \%$ & 3 & 3 & 4 \\
$21 \%-40 \%$ & 0 & 0 & 0 \\
$\leq 20 \%$ & 0 & 0 & 0 \\
\hline
\end{tabular}

The activities of students can be described as follow:

Visual activities

Visual Activities are activities in the form of activities while reading, paying attention to pictures, demonstrations, experiments, and work being done by other people [22]. An activity like reading is an option that we can use to stimulate students' motivation in learning physics [23]. The visual activities give the average achievement at $80.77 \%$, which belongs to the good category. The implementation of students' worksheets based on predict-observe-explain makes students giving more pay attention to teacher or peers' explanations because the students are demanded to practice the experiment. And they will feel left out if they are not concerned with the explanation from others. Students also observe the practicum and the video well because they feel curious about the experiment. One of the participants said:

"The activities presented in the worksheet can foster my curiosity. So I always take the learning path seriously."

With the hands-on activity such as the worksheet, the students' curiosity can be developed deeply so it will arouse students to conduct research to gain experience in the scientific process [24]. But the willingness of students to search and read the various literature is still weak. Students prefer to practice the experiment directly without searching the materials in the literature at the beginning. It is 
because reading scientific problems requires several strategies. Besides think of questions that arise after reading, at the same time, students should be able to predict and think about what kind of subject matter they should read afterward to obtain the information needed. Then, the students read in more detail to get the answer [25].

\section{Oral activities}

Oral activities include expressing an idea or opinion, formulating, asking, giving suggestions, discussing, and giving interruptions [7]. This aspect is the aspect with the lowest achievement of other aspects at $59.83 \%$, with enough criteria. This is because most students do not dare to speak either to answer questions or ask questions. The students are afraid to express their ideas and question. They think that their idea would be wrong. They also feel confused because they had no idea about the question they want to ask. One of the students argued that:

$$
\begin{aligned}
& \text { "I don't like speaking in public. I rather listen to my friends' argument than try to } \\
& \text { express my own." }
\end{aligned}
$$

Other students said:

\section{"I prefer to silent. I feel that I understand material learning. But I am confused about telling others about my idea."}

Students are not confident to tell their idea because they are not optimal in linking predictions with the observations made and are not accustomed to appearing before their peers [15]. Students who are actively expressing their idea and give a strong theoretical explanation are students who have more references reading [25].

\section{Writing activities}

The writing activities give the highest score for all of the activities at 100\%. It means that all of the students answer the question in the worksheet even though the answer is not correct. At least, students have tried to write their inventions and arguments. Writing activities are very important to build knowledge for high school students. These activities can enable students to raise awareness and express the idea, develop abstract thinking, and stimulate reasoning related to scientific knowledge [26]. One of the participants said:

"This worksheet is very interesting. The image used in the sheet can catch my eye. So I became more passionate to write."

Other participant said that:

"The sentences used in the worksheet are communicative, and it's easy for me to understand so that I'm not confused about answering questions on the worksheet."

The students also take the note in their book about the data and the conclusion of the experiment. They argue that they are used to write the material from the teacher as usual. The high percentage of aspect writing is because it has often been done in the class [11] before using students' worksheets based on predict-observe-explain.

\section{Motor activities}

Diedrich said that motor activities are the activities in the form of conducting an experiment and making construction or model [27]. The motor activities give the average achievement at $97.44 \%$, which is included as a very good category. One student said:

"Through the experiment, I got a lot of interesting knowledge because I feel that the experiment is near my life." 
Learning by doing is student-centered learning. This will develop the three domains in learning (cognitive, affective, and psychomotor) [24]. The involvement of students directly in the classroom can help students find the fact of the teacher's theories through the scientific work [28]. The skills that can be gained through motor activities are the skills of relating the abstract and concrete concepts [24]; the skills of creating hypotheses, observation, data recording, measurement, and classification. The motor activities also can gain the ability to determine, changing, and controlling variables [28].

\section{Mental activities}

Mental activities are the activities when students respond, remember an incident, solve a problem, analyze it, and make decisions [27]. The mental activities give the average achievement at $84.62 \%$, which is included as a very good category. In the learning process using students' worksheets based on predict-observe-explain, students are divided into several groups. One participant said:

"I feel that the activity gives benefit to each student because if I have difficulties in learning, so I will be helped by my friends."

Students prefer to actively learn material such as in a predict-observe-explain learning strategy using group division over the traditional class. They feel that they can learn more, enjoy the classroom environment, and like to interact with their friends [5].

This research in line with the result of the research by Fatwadi et al that explains that by using the POE learing model, students become more active. They no longer just sit listening to their teacher's explanation and taking notes but also participate actively in the class. The students' learning activities have increased from 2.08 in cycle I to 2.36 in cycle II [15]. Banjarnahor et al said that the learning activities in the class using a POE model (mean $=70.68$ ) are more effective than in the Direct Instruction class (50.33) [16]. But the least activities that the students do are the oral activities. Gima et al [29] and Banjarnahor et al [16], in their research, said that the oral activities in the learning model using the peers' group and experiment are the lowest activities achieved by the student. This can happen because learning by using the POE approach is not always easy to apply due to classroom management's difficulty that can affect students' frequently underestimate and depend on their peers [13].

\section{CONCLUSION AND SUGGESTION}

Based on the results above, it can be concluded that the students' worksheet based on predict-observeexplain can be used to enhance students' learning activities, especially in visual activities, oral activities, writing activities, motor activities, and mental activities with the most dominant activities is writing activities and the weakest one is oral activities. Students sit and listen to their teacher's explanation and are given a chance to be involved directly in the demonstration and the practicum. Besides, students feel that using students' worksheets based on predict-observe-explain can create their curiosity, make them even more seriously in the study, increase the interest in studying physics and help each other with their friends. But, the students' confidence and speaking ability must be the concern in learning whose one of its learning steps is explaining. So students are not reluctant to share their idea in front of the class. In future research, it is necessary to research each student's learning activities concerning the dominant characteristics of students in visual, aural, and motor skills.

\section{REFERENCES}

[1] Bao, L., \& Koenig, K. (2019). Physics education research for 21 st century learning. Disciplinary and Interdisciplinary Science Education Research, 1(1): 1-12.

[2] Septiani, T., Yulikifli, \& Havid, M. (2020, March). Preliminary analysis of student worksheets 
development with multi-representation approach on 21 st century physics learning. In Journal of Physics: Conference Series (Vol. 1481, No. 1, p. 012071). IOP Publishing.

[3] Durk, J., Davies, A., Hughes, R., \& Jardine-Wright, L. (2020). Impact of an active learning physics workshop on secondary school students' self-efficacy and ability. Physical Review Physics Education Research, 16(2): 020126.

[4] Handayani, R. A. D., \& Genisa, M. U. (2019). Empowering Physics Students' Performance in a Group Discussion through Two Types of Peer Assessment. International Journal of Instruction, 12(1): 655-668.

[5] Henderson, C., Khan, R., \& Dancy, M. (2018). Will my student evaluations decrease if I adopt an active learning instructional strategy?. American Journal of Physics, 86(12): 934-942.

[6] Wang, J. Y., Wu, H. K., \& Hsu, Y. S. (2017). Using mobile applications for learning: Effects of simulation design, visual-motor integration, and spatial ability on high school students' conceptual understanding. Computers in Human Behavior, 66: 103-113.

[7] Telaumbanua, D. (2017). Experimental Method Application In Teaching Physics Education. Asian Journal of Social Sciences \& Humanities Vol, 6(4): 84-90.

[8] Subekti, Y., \& Ariswan, A. (2016). Pembelajaran fisika dengan metode eksperimen untuk meningkatkan hasil belajar kognitif dan keterampilan proses sains. Jurnal Inovasi Pendidikan IPA, 2(2): 252-261.

[9] Istiyono, E. (2020). Pengembangan Instrumen Penilaian dan Analisis Hasil Belajar Fisika dengan Teori Tes Klasik dan Modern. Yogyakarta: UNY Press.

[10] Sumardani, D., Putri, A., Ramadhan, Z., Bakri, F., \& Muliyati, D. (2020). Augmented Physics' Lab: Magnetic Field Use Virtual Learning Media for 21st Century Students. Jurnal Pembelajaran Fisika, 8(1): 61-70.

[11] Purnamasari, U. A., \& Arifuddin, M. (2018). Meningkatkan Aktivitas Belajar Siswa Pada Mata Pelajaran IPA Dengan Model Pembelajaran Kooperatif Tipe Group Investigation. Berkala Ilmiah Pendidikan Fisika, 6(1): 130-141.

[12] Bunprom, S., Tupsai, J., \& Yuenyong, C. (2019, October). Learning Activities to Promote the Concept of Engineering Design Process for Grade 10 Students' Ideas about Force and Motion through Predict-Observe-Explain (POE). In Journal of Physics: Conference Series (Vol. 1340, No. 1, p. 012081). IOP Publishing.

[13] Pane, A. N., Nyeneng, I., \& Distrik, I. W. (2020). The Effect of Predict Observe Explain Learning Model Against Science Process Skills of High School Students. Jurnal Pendidikan Matematika dan IPA, 11(1): 111-119.

[14] Rosdianto, H., \& Murdani, E. (2017). The implementation of POE (Predict Observe Explain) model to improve student's concept understanding on Newton's law. Jurnal Pendidikan Fisika, 6(1): 55-57.

[15] Fatwadi, A., Gummah, S., \& Prasetya, D. S. B. (2019). Implementation of POE Learning Model with Worksheets Assistance to Improve Students' Activities and Learning Outcomes. Lensa: Jurnal Kependidikan Fisika, 7(1): 10-14.

[16] Banjarnahor, J. A., \& Silitonga, M. (2017). Perbedaan Hasil Belajar dan Aktivitas Siswa dengan Menggunakan Model Pembelajaran Predict-Observe-Explain (POE) dan Model Direct Instruction. Jurnal Pelita Pendidikan, 6(3).

[17] Zakiyah, I., \& Widodo, W. (2020, June). Profile of student's conception in implementation of predict-observe-explain (POE) strategy on thermochemistry concept. In Journal of Physics: Conference Series (Vol. 1567, No. 3, p. 032104). IOP Publishing.

[18] Latifah, S., Irwandani, I., Saregar, A., Diani, R., Fiani, O., Widayanti, W., \& Deta, U. A. (2019, February). How the Predict-Observe-Explain (POE) learning strategy remediates students' misconception on Temperature and Heat materials?. In Journal of Physics: Conference Series (Vol. 1171, No. 1, p. 012051). IOP Publishing.

[19] Jamieson, S. (2016). Analyse qualitative data. Education for Primary Care, 27(5): 398-402.

[20] Azwar, S. (2012). Metode Penelitian. Yogyakarta: Pustaka Pelajar.

[21] Chiu, J. L., DeJaegher, C. J., \& Chao, J. (2015). The effects of augmented virtual science laboratories on middle school students' understanding of gas properties. Computers \& Education, 85: 59-73. 
[22] Sardiman. (2016). Interaksi dan Motivasi Belajar Mengajar. Jakarta: Rajawali Press.

[23] Muttaqiin, A., \& Sopandi, W. (2017, September). Energy Transformation Topic: Correlation between Pre-Classroom Reading Activity and Students' Curiosity. In Journal of Physics: Conference Series (Vol. 895, No. 1, p. 012021). IOP Publishing.

[24] Fauziah, I., Mariani, S., \& Isnarto, I. (2017). Kemampuan Penalaran Geometris Siswa pada Pembelajaran RME dengan Penekanan Handso on Activity Berdasarkan Aktivitas Belajar. Unnes Journal of Mathematics Education Research, 6(1): 30-37.

[25] Probosari, R. M., Widyastuti, F., Sajidan, S., Suranto, S., \& Prayitno, B. A. (2018, May). Reading for tracing evidence: developing scientific knowledge through science text. In Journal of Physics: Conference Series (Vol. 1022, No. 1, p. 012019). IOP Publishing.

[26] Setlik, J., \& Higa, I. (2018). Writing in Physics classes in High School: possibilities. International Journal of Physics \& Chemistry Education, 10(2): 55-65.

[27] Sadirman, A. M. (2011). Interaksi dan Motivasi Belajar Mengajar. Jakarta: Rajawali Press.

[28] Sumarni, W., Wardani, S., Sudarmin, S., \& Gupitasari, D. N. (2016). Project Based Learning (PBL) to improve psychomotoric skills: A classroom action research. Jurnal Pendidikan IPA Indonesia, 5(2): 157-163.

[29] Nurhamidah, G., Syaripudin, T., \& Riyadi, A. R. (2016). Penerapan Model TS-TS untuk Meningkatkan Aktivitas dan Hasil Belajar Siswa Sekolah Dasar. Jurnal Pendidikan Guru Sekolah Dasar, 4(2): 293-303. 